\title{
Effects of the Pesticide Furadan on Traits Associated with Reproduction in Wild Potato Species
}

\author{
Alfonso del Rio ${ }^{1}$, John Bamberg ${ }^{1}$, Ruth Centeno-Diaz ${ }^{2}$, Alberto Salas ${ }^{2}$, William Roca ${ }^{2}$, David Tay $^{2}$ \\ ${ }^{1}$ USDA/Agriculture Research Service, US Potato Genebank, Wisconsin, USA; ${ }^{2}$ International Potato Center (CIP), Lima, Peru. \\ Email: adelrioc@wisc.edu
}

Received August $5^{\text {th }}, 2012$; revised September $18^{\text {th }}, 2012$; accepted October $20^{\text {th }}, 2012$

\begin{abstract}
Natural populations of wild potato species are the backups for the diversity held in genebanks for research and breeding. Some potato species are known to grow in close proximity to cultivated fields, thus are potentially impacted by human activity, including exposure to pesticides. The present study tested the effects of a common pesticide on reproductive traits of potatoes known to grow in or near pesticide-treated fields in central Peru. Furadan ${ }^{\circledR} 4 \mathrm{~F}$, an insecticidenematicide $($ common name $=$ carbofuran $)$ was applied at two different rates to populations representing 15 wild potato species in a greenhouse environment in Peru. Flowering duration of these populations was usually significantly reduced in comparison to a water control, and in a few cases, percent viable pollen also was. These findings suggest that agrichemicals may be having unintentional effects on wild potato populations in ways that could compromise their genetic diversity.
\end{abstract}

Keywords: Potato Species; Pesticide Contamination; Genetic Drift; Reproductive Capacity

\section{Introduction}

Wild potato populations are being impacted by human activity, most extremely when they go extinct, per se, as a result of having their habitats converted to some other uses (Coca-Morante and Castillo-Plata, 2007) [1]. But more subtle influences may be occurring, perhaps only eliminating specific traits or otherwise narrowing the genetic base of populations.

According to a recent taxonomic estimate by Spooner (2009) [2], potato wild relatives are represented by about 100 species which are distributed in many different types of eco-geographic niches from the southwestern USA to southern Chile (Hijmans and Spooner, 2001) [3]. Some are known to grow within or very close to fields in which potato or other crops are cultivated. Pesticides are used in virtually all potato fields in the Andean region. These fields receive up to seven pesticide applications per season with each application averaging 2 - 3 different products (Yanggen et al., 2003) [4]. Carbofuran and metamidofos are the major insecticides used and constitute $47 \%$ and $43 \%$, respectively, of all the active ingredients applied (Forbes et al., 2009) [5].

Flowering and pollen production are essential in plant sexual reproduction, so changes could impact genetic diversity and population fitness (Ennos 1994 [6]; Hamrick et al., 1979 [7]; Loveless and Hamrick, 1984 [8]).
There is evidence that agrichemicals can alter plant biochemistry and metabolic mechanisms as well as disrupt mitotic and meiotic cycles in plants. Application of pesticides was related to the modulation of the biosynthetic pathways leading to polyphenol formation in peas, oats, potatoes, raspberries, etc. (Daniel et al., 1999) [9] and, Lydon and Duke (1989) [10] reported significant changes in the content of secondary compounds. Asita and Matebesi (2010) [11] found that pesticides caused cytotoxic and genotoxic effects in root meristems of Allium cepa, Vicia faba and Zea mays. These effects varied from point mutations to chromosome aberrations. Other studies indicated that fungicides affected germination, mitotic and meiotic activity, and pollen fertility in barley and tomatoes (Behera et al. 1982 [12]; Fairbanks et al. 2002 [13]; Tort et al. 2005 [14]), pollen viability in tomatoes (Cali and Candan 2009) [15] and flower production in different species (Spiers et al. 2006) [16]. The literature, however, does not report impacts of agrichemicals in species related to potatoes.

Ahmad et al. (1979) [17] reported that site-specific environmental variables determine persistence of pesticides and their biological impact. For example, while carbofuran degrades rapidly at high soil $\mathrm{pH}$, Finlayson et al. (1979) [18] estimated it has a half-life of about 16 years in soils of $\mathrm{pH}$ 5.5. The $\mathrm{pH}$ of the Andes soils, from which the species tested in our study originated, are 
known to be very acidic-sometimes lower than $\mathrm{pH} 4.0$ (Arica et al. 2006) [19]. It follows that yearly applications could result in buildup of carbofuran in the soil. For this reason, the effects of exposure of wild species to levels higher than the recommended rate were also of practical interest.

The present study was initiated to assess flowering and pollen viability effects in wild potato populations after controlled application of carbofuran, a pesticide to which they would likely be unintentionally exposed in the farm field setting.

\section{Methods and Materials}

\subsection{Plant Material}

Twenty-one populations from 15 different potato species from diverse regions in the Andes were selected because of their known natural proximity to farm fields. Plants used in this study originated as botanical seed from CIP's potato germplasm collection. Table 1 provides identities and other details of the plant material used.

\subsection{Pesticide Selection and Application}

A survey of farmer's communities at Quilca, Colpar and Nunhuayo in the Mantaro Valley confirmed that Furadan $^{\mathbb{B}}$ as the most consistently-used pesticide in the region ( $100 \%$ of farmers). The responses were gathered from interviews made to 14 potato farmers who were leaders and responsible of agricultural decisions in their respective communities. Furadan ${ }^{\circledR}$ is the commercial name for Carbofuran (2,3-dihydro-2,2-dimethyl-7-benzofuranyl methylcarbamate), a carbamate with insecticidal and nematicidal properties resulting from inhibition

Table 1. Identities and origins of wild potato populations used in this study.

\begin{tabular}{|c|c|c|c|}
\hline Solanum... ${ }^{\mathrm{a}}$ & Population code ${ }^{b}$ & Chromosome number & Original location (site, province, elevation) \\
\hline acl & OCH 11322 & 48 & Huarochiri, Lima, $3154 \mathrm{~m}$ \\
\hline acl & OCHS 11889 & 48 & Acora, Puno, $3840 \mathrm{~m}$ \\
\hline$a l b$ & OCH 11842 & 72 & Kawish, Ancash, $4200 \mathrm{~m}$ \\
\hline$a l b$ & OCHS 16023 & 72 & Shojlla, Cajamarca, $3550 \mathrm{~m}$ \\
\hline$a m b$ & OCHS 11865 & 24 & Choccec, Pasco, $2800 \mathrm{~m}$ \\
\hline buk & HJT 5444 & 24 & Lircay, Huancavelica, $3800 \mathrm{~m}$ \\
\hline buk & OCH 13713 & 24 & Ckumuccacca, Cusco, $3650 \mathrm{~m}$ \\
\hline$c h q$ & OCH 13963 & 24 & Cajon, Cajamarca, $2850 \mathrm{~m}$ \\
\hline hcr & OCH 11692 & 24 & Llusupuquio, Ancash, $2800 \mathrm{~m}$ \\
\hline $\operatorname{lgl}$ & OCH 11617 & 24 & Intihuatana, Cusco, $2800 \mathrm{~m}$ \\
\hline $\operatorname{lmb}$ & SS 7205 & 24 & Phara, Puno, $3640 \mathrm{~m}$ \\
\hline med & OCH 12044 & 24 & Surco, Lima, $2240 \mathrm{~m}$ \\
\hline med & SSTS 7302 & 24 & Hongos, Lima, $2880 \mathrm{~m}$ \\
\hline$m g a$ & OCH 11941a & 24 & Mollepunco, Potosi ${ }^{\mathrm{d}}, 3880 \mathrm{~m}$ \\
\hline$m t p$ & OCHS 11307 & 24 & Canta, Lima, $2800 \mathrm{~m}$ \\
\hline rap & HHCH 5141 & 24 & Sacsayhuaman, Cusco, $3550 \mathrm{~m}$ \\
\hline rap & OCH 13626 & 24 & Paucarpata, Cusco, $3800 \mathrm{~m}$ \\
\hline spl & SS 7213 & 24 & Tarapata, Cusco, $2900 \mathrm{~m}$ \\
\hline $\operatorname{trp}$ & OCHB 15687a & 24 & Luruchayocc, Cusco, $3400 \mathrm{~m}$ \\
\hline $\operatorname{trp}$ & SS 7216 & 24 & Tarapata, Cusco, $3200 \mathrm{~m}$ \\
\hline uru & SS 7225 & 24 & Vilcabamba, Cusco, $2600 \mathrm{~m}$ \\
\hline
\end{tabular}

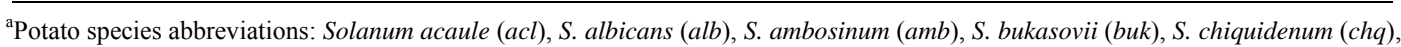
S. hypacarthrum (hcr), S. lignicaule (lgl), S. limbaniense ( $\operatorname{lmb})$, S. medians (med), S. megistracolobum (mga), S. multiinterruptum (mtp), S. raphanifolium (rap), S. sparsifilum (spl), S. tarapatanum (trp) and, S. urubambae (uru); ${ }^{b}$ Population code represents the

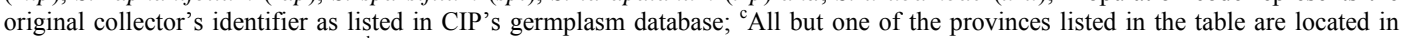
Peru; $\mathrm{m}=$ meters above sea level; ${ }^{\mathrm{d}}$ Province of Bolivia. 
of cholinesterase, which catalyzes the neurotransmitter acetylcholine. Furadan ${ }^{\circledR}$ is systemic, with high water solubility and rapid uptake from roots and leaves (PAN 2008) [20].

The experiment was conducted in the greenhouses at CIP's Santa Ana Station in Huancayo, Peru $\left(12.067^{\circ} \mathrm{S} \times\right.$ $75.217^{\circ} \mathrm{W} ; 3380 \mathrm{~m}$ ) in the summer (January-March). Each of the 21 populations was replicated 3 times in a Completely Random Design with experimental units composed of 5 seedlings each. Seeds were sown and transplanted into $20 \mathrm{~cm}$ plastic pots filled with a mix of soil and peat moss, and fertilized and hand watered as standard for optimal growth. Furadan ${ }^{\circledR}$ in liquid form (480 g/L active ingredient) was obtained from Farmagro S.A., Lima. Two treatment concentrations (per liter) were applied: $\operatorname{trt}_{3.5}=3.5 \mathrm{ml}, \operatorname{trt}_{4.5}=4.5 \mathrm{ml}$, and compared to control plants. Leaves of all plants were sprayed to drip a total of 5 times at 10-day intervals over the growing season. The control plants (similarly sprayed but with pure water) were grown in a separate greenhouse to prevent accidental exposure to the pesticide.

\subsection{Trait Evaluation}

Flowering was considered to have begun when at least one plant in the experimental unit had five inflorescences in bud stage, and to have ended when all flowers had dried up. Plants were inspected daily to see if these conditions were met. Pollen was collected from each population at estimated peak flowering, from at least one flower from each plant in the experimental unit. Pollen grains were collected by mechanical vibration using a doorbell buzzer and were examined microscopically in a $2 \%$ solution of acetocarmine glycerol. The average percent stained pollen was recorded for three random fields of view at $40 \times$. Acetocarmine is not a vital stain per se, but staining indicates that normal pollen development has occurred, so unstained grains were considered inviable.

Analysis of variance was conducted using JMP statistical software (JMP9 2011) [21] to calculate treatment's LSD in each trait assessed. In the test of pollen viability, percentdata were arcsine transformed before analysis.

\section{Results and Discussion}

\subsection{Flowering Duration}

Populations varied in control flowering duration from 30 to 79 days (see Table 2). The standard application of Furadan ( $\left.\operatorname{trt}_{3.5}\right)$ commonly depressed flowering duration at average of $25 \%$ relative to controls (from 48 to 36 days), which was significant $(\mathrm{p}<0.05)$ for 17 of the 21 populations examined. Populations with more robust control flowering tended to be reduced more in response to Furadan exposure. Note for example, that the four populations which did not show significant reduction in response to Furadan application all had among the lowest control flowering. The mechanism responsible for the observed differences in pesticide sensitivity is not known, but it is common for a pesticide to be toxic to one plant species and not to another (Dalvi et al. 1972 [22]; Pereira et al. 2010 [23]). Increasing the dosage to $\operatorname{trt}_{4.5}$ did not often result a significant additional reduction of flowering duration-being the case in only for three of the populations.

\subsection{Stainable Pollen Percent}

Pollen viability estimates were very high in control, averaging $91 \%$ and ranging from $75 \%$ to $100 \%$ (see Table 2). Standard Furadan application $\left(\operatorname{trt}_{3.5}\right)$ reduced percent stainable pollen by an average of only about $7 \%$, and only significantly in 3 of the 21 populations. The greatest effect was found in populations of buk and $\mathrm{lgl}$, where pollen viability was reduced by $25 \%$ and $24 \%$, respectively. In three other populations, the higher dose $\left(\operatorname{trt}_{4.5}\right)$ resulted in significant reduction compared to control. While Furadan treatment never resulted in a substantial increase in flowering duration, in one case (med-OCH 12044), it appeared to increase percent stainable pollen. This coincided with particularly low percent stainable pollen in the corresponding control plants. This observation implies need for follow-up experiments to confirm the pollen viability-enhancing effect of Furadan and identify the sub-optimal control environment conditions that the presence of Furadan apparently improves in some germplasm.

This experiment was not designed to differentiate species according to Furadan effects, nor associate flowering and pollen effects in a given population. However, results in Table 2 do not suggest any obvious pattern of species susceptibility, and the correlation between Furadan impact on flowering and pollen viability is a non-significant $-26 \%$, suggesting no obvious link between the two.

\subsection{Potential Impact on Potato Genetic Diversity}

Solanum species and other native plants in the Andes often compete for the same few insect pollinators that are available at high elevations. Altered flowering could divert bees to other plants and impact potato reproduction potential by suppressing (or limiting) pollination (Husband and Schemske 1996) [24]. The prospects of population genetic impact seem particularly relevant considering that majority of the potato species examined here are diploid obligate out crossers (Table 1) - a breeding system that is vulnerable to genetic drift when effective population size is restricted (Bamberg and del Rio 2004 [25]; Loveless and Hamrick 1984) [8]. 
Table 2. Effects of Furadan treatments on flowering and pollen of wild potato species.

\begin{tabular}{|c|c|c|c|c|c|c|c|}
\hline \multirow{2}{*}{ Species $^{1}$} & \multirow{2}{*}{ Population } & \multicolumn{3}{|c|}{ Flowering Duration (Days) ${ }^{2}$} & \multicolumn{3}{|c|}{ Stainable Pollen Percent ${ }^{3}$} \\
\hline & & Control & $\operatorname{trt}_{3.5}$ & $\operatorname{trt}_{4.5}$ & Control & $\operatorname{trt}_{3.5}$ & $\operatorname{trt}_{4.5}$ \\
\hline acl & OCH 11322 & 53 & $37^{*}$ & 36 & 99 & 95 & 93 \\
\hline acl & OCHS 11889 & 52 & $24^{*}$ & 21 & 100 & 99 & 87 \\
\hline alb & OCH 11842 & 79 & $53^{*}$ & 48 & 99 & 95 & 93 \\
\hline alb & OCHS 16023 & 69 & $57^{*}$ & 51 & 97 & 93 & 92 \\
\hline$a m b$ & OCHS 11865 & 39 & $27^{*}$ & 22 & 75 & 83 & $67^{*}$ \\
\hline$b u k$ & HJT 5444 & 36 & 36 & 31 & 95 & $71^{*}$ & 89 \\
\hline buk & OCH 13713 & 51 & $44^{*}$ & 41 & 94 & 88 & 90 \\
\hline$c h q$ & OCH 13963 & 49 & $38^{*}$ & 36 & 90 & 83 & 81 \\
\hline hor & OCH 11692 & 50 & $34^{*}$ & $24^{*}$ & 84 & 76 & 77 \\
\hline $\operatorname{lgl}$ & OCH 11617 & 49 & $39^{*}$ & 33 & 96 & $73^{*}$ & 70 \\
\hline $\operatorname{lmb}$ & SS 7205 & 62 & $42^{*}$ & 41 & 91 & 84 & 79 \\
\hline med & OCH 12044 & 42 & 37 & $28^{*}$ & 78 & $91+$ & 90 \\
\hline med & SSTS 7302 & 43 & $36^{*}$ & 31 & 93 & 89 & 89 \\
\hline$m g a$ & OCH 11941a & 38 & $23^{*}$ & 23 & 82 & 73 & 73 \\
\hline$m t p$ & OCHS 11307 & 40 & $26^{*}$ & 27 & 91 & 80 & 88 \\
\hline rap & НJTCH 5141 & 30 & 31 & $23^{*}$ & 93 & $81^{*}$ & 90 \\
\hline rap & OCH 13626 & 50 & $37^{*}$ & 34 & 96 & 96 & 97 \\
\hline spl & SS 7213 & 39 & $24^{*}$ & 22 & 93 & 94 & 94 \\
\hline $\operatorname{trp}$ & OCHB $15687 \mathrm{a}$ & 35 & 29 & 30 & 92 & 84 & $78 * \mathrm{c}$ \\
\hline $\operatorname{trp}$ & SS 7216 & 57 & $36^{*}$ & 40 & 78 & 75 & $68 * \mathrm{c}$ \\
\hline uru & SS 7225 & 52 & $39^{*}$ & 37 & 96 & 87 & $84 * \mathrm{c}$ \\
\hline \multicolumn{2}{|c|}{ Averages } & 48 & $36^{*}$ & 32 & 91 & $85^{*}$ & 84 \\
\hline
\end{tabular}

${ }^{1}$ See Table 1 for full species names; ${ }^{2} \mathrm{LSD}_{0.05}$ flowering duration $=8.53 ;{ }^{3} \mathrm{LSD}_{0.05}$ stainable pollen percentage pollen $=10.63 ;$ Control $=$ water, trt $3.5=3.5 \mathrm{ml} / \mathrm{L}$, $\operatorname{trt}_{4.5}=4.5 \mathrm{ml} / \mathrm{L} ;+=$ significantly greater than control; trt $1^{*}=$ significantly less than control, trt $2^{*}=$ significantly less than trt1 and control; trt $2^{*} \mathrm{c}=$ significantly less than control but not sign less than trt1.

The significance of human influence on in situ germplasm depends on the sensitivity of the germplasm in question, the level of exposure, and the value/rarity of the germplasm with respect to agriculture and the ecosystem. This preliminary survey demonstrated that the pesticide Furadan, to which in situ germplasm may be expected to have high exposure, can indeed have a negative influence on reproductive indicators in greenhousegrown plants. More focused follow-up studies are in progress to better characterize the patterns and mechanisms by which these reproductive traits are depressed, and quantify the consequences on genetic diversity that could logically follow in the wild.

\section{Acknowledgements}

The authors wish to express thanks to the staff of CIPSanta Anta Agricultural Station in Huancayo, Peru for their cooperation and technical assistance.

\section{REFERENCES}

[1] M. Coca-Morante and W. Castillo-Plata, "Wild Potato Species Threatened by Extinction in the Department of La Paz, Bolivia," Spanish Journal of Agricultural Research, Vol. 5, No. 4, 2007, pp. 487-496.

[2] D. M. Spooner, "DNA Barcoding Will Frequently Fail in Complicated Groups: An Example in Wild Potatoes," American Journal of Botany, Vol. 96, No. 6, 2009, pp. 1177-1189. doi:10.3732/ajb.0800246

[3] R. J. Hijmans and D. M. Spooner, "Geographic Distribution of Wild Potato Species," American Journal of Botany, Vol. 88, No. 11, 2001, pp. 2101-2112. doi: $10.2307 / 3558435$

[4] D. Yanggen, C. Crissman and P. Espinoza, "Los Plaguicidas, Impactos en Producción, Salud y Medio Amb- 
iente en Carchi," CIP and INIAP. Abya-Yala, Eds., Quito, Ecuador, 2003, 199 p.

[5] V. E. Forbes, U. Hommen, P. Thorbek, F. J. Heimbach, P. J. Van den Brink, J. Wogram, H. H. Thulke and V. Grimm, "Ecological Models in Support of Regulatory Risk Assessments of Pesticides: Developing a Strategy for the Future," Integrated Environmental Assessment and Management, Vol. 5, No. 1, 2009, pp. 167-172. doi:10.1897/IEAM 2008-029.1

[6] R. A. Ennos, "Estimating the Relative Rates of Pollen and Seed Migration among Plant Populations," Heredity, Vol. 72, 1994, pp. 250-259. doi:10.1038/hdy.1994.35

[7] J. L. Hamrick, Y. B. Linhart and J. B. Mitton, "Relationships between Life History Characteristics and Electrophoretically Detectable Genetic Variation in Plants," Annual Review of Ecology and Systematics, Vol. 10, 1979, pp. 173-200. doi:10.1146/annurev.es.10.110179.001133

[8] M. D. Loveless and J. L. Hamrick, "Ecological Determinants of Genetic Structure in Plant Populations," Annual Review of Ecology and Systematics, Vol. 15, No. 1, 1984, pp. 65-95. doi:10.1146/annurev.es.15.110184.000433

[9] O. Daniel, M. S. Meier, J. Schlatter and P. Frischknecht, "Selected Phenolic Compounds in Cultivated Plants: Ecologic Functions, Health Implications, and Modulation by Pesticides," Environmental Health Perspectives, Vol. 107, No. 1, 1999, pp. 109-114. doi:10.1289/ehp.99107s1109

[10] J. Lydon and S. O. Duke, "Pesticide Effects on Secondary Metabolism of Higher Plants," Pesticide Science, Vol. 25, No. 4, 1989, pp. 361-373. doi:10.1002/ps.2780250406

[11] A. O. Asita and L. P. Matebesi, "Genotoxicity of Hormoban and Seven Other Pesticides to Onion Root Tip Meristematic Cells," African Journal of Biotechnology, Vol. 9, No. 27, 2010, pp. 4225-4232.

[12] B. N. Behera, R. K. Sahu and C. B. S. R. Sharma, "Cytogenetic Hazards from Agricultural Chemicals; Sequential Screening in the Barley Progeny: Test for Cytogenetic Activity of Some Systemic Fungicides and a Metabolite," Toxicology Letters, Vol. 10, No. 2-3, 1982, pp. 195-203. doi:10.1016/0378-4274(82)90074-1

[13] M. M. Fairbanks, G. E. J. St. Hardy and J. A. McComb, "Mitosis and Meiosis in Plants Are Affected by the Fungicide Phosphate," Australasian Plant Pathology, Vol. 31, No. 3, 2002, pp. 281-289. doi:10.1071/AP02025

[14] N. Tort, I. Ozturk and A. Guvensen, "Effects of Some Fungicides on Pollen Morphology and Anatomy of Tomato (Lycopersiconesculentum Mill.)," Pakistan Journal of Botany, Vol. 37, 2005, pp. 23-30.
[15] I. O. Cali and F. Candan, "Effects of a Fungicide on the Morphology and Viability of Pollens of Tomato (Lycopersiconesculentum Mill.)," Bangladesh Journal of Botany, Vol. 38, 2009, pp. 115-118.

[16] J. D. Spiers, F. T. Davies, C. He, C. Bográn, K. M. Heinz, T. W. Starman and A. Chau, "Effects of Insecticides on Gas Exchange, Vegetative and Floral Development, and Overall Quality of Gerbera," HortScience, Vol. 41, No. 3, , pp. 701-706.

[17] N. Ahmad, D. D. Walgenbach and G. R. Sutter, "Degradation Rates of Technical Carbofuran and a Granular Formulation in Four Soils with Known Insecticide Use History," Bulletin of Environmental Contamination and Toxicology, Vol. 23, No. 1, 1979, pp. 572-574. doi:10.1007/BF01770005

[18] D. G. Finlayson, J. R. Graham, R. Greenhalgh, J. R. Roberts, E. A. H. Smith, P. Whitehead, R. F. Willes and I. Williams, "Carbofuran: Criteria for Interpreting the Effects of Its Use on Environmental Quality," National Research Council Canada, Publ. NRCC 16740, 1979, 191 p.

[19] D. Arica, J. Kroschel, G. Forbes and K. St. Pere, "Persistent Organic Pollutants and Hazardous Pesticide in Andean Farming Communities in Peru-Final Report," International Potato Center, Lima, 2006, 48 p.

[20] PAN (Pesticide Action Network), "PAN Pesticide Database, Version 8.0," 2008. http://www.pesticideinfo.org/

[21] JMP 9, “Statistical Discovery. Version 9.0.0," Statistical Analysis System Institute Inc., Cary, 2011.

[22] R. R. Dalvi, B. Singh and D. K. Salunkhe, "Influence of Selected Pesticides on Germination and Associated Metabolic Changes in Wheat and Mung Bean Seeds," Journal of Agricultural and Food Chemistry, Vol. 20, No. 5, 1972, pp. 1000-1003. doi:10.1021/jf60183a034

[23] R. Pereira, C. Monterroso and F. Macias, "Phytotoxicity of Hexachlorocyclohexane: Effect on Germination and Early Growth of Different Plant Species," Chemosphere, Vol. 79, No. 3, 2010, pp. 326-333. doi:10.1016/j.chemosphere.2010.01.035

[24] B. C. Husband and D. W. Schemske, "Evolution of the Magnitude and Timing of Inbreeding Depression in Plants," Evolution, Vol. 50, No. 1, 1996, pp. 54-70. doi: $10.2307 / 2410780$

[25] J. B. Bamberg and A. H. del Rio, "Genetic Heterogeneity Estimated by RAPD Polymorphism of Four Tuber-Bearing Potato Species Differing by Breeding Structure," American Journal of Potato Research, Vol. 81, 2004, pp. 377-383. doi:10.1007/BF02870198 